\title{
Minimally Invasive Lung Mucinous Adenocarcinoma
}

National Cancer Institute

\section{Source}

National Cancer Institute. Minimally Invasive Lung Mucinous Adenocarcinoma. NCI

Thesaurus. Code C7268.

A morphologic variant of minimally invasive lung adenocarcinoma characterized by tall columnar cells and mucin production. 